\title{
Let 100 Mandelas Bloom: Who Needs Prisons and Who do the Prisons Need? Veronza Bowers
}

The following interview was broadcastlive on the program "YouthSpeaksOut" on KZYX/Z radio, Philo California. It was produced by Dan Roberts and Eda Levenson.

Eda Levenson: I'm currently a freshman at UC Santa Cruz. For four years I have been in contact with a man who has spent the last thirty-two years of his life in prison. His name is Veronza Bowers, Jr. Before his incarceration, he was a member of the Black Panther Party during the Sixties. At twentysix years old he was convicted of the murder of a Park Ranger-although the legitimacy of his trial is questionable, due to the lack of physical evidence and the reliability of the key witnesses. To this day, Veronza claims his innocence, and that the FBI framed him. He is currently being held in a federal penitentiary in Coleman, Florida. Last June, my family and I visited Veronza. This is the first time that any of us, including my father, who has known him for fifteen years, has seen Veronza in person. During our visit I brought up the idea of doing a telephone interview. After months of negotiation, and being denied once by the assistant warden of the prison, I was finally granted permission to interview Veronza over the phone. On September 11, 2002, I conducted the interview. Because of his circumstances we could only talk in fifteen minute segments, with fifteen minute breaks in between each one.

September 11, 2002: This call is from a federal prison. This is a pre-paid call... This call is from Veronza.

Veronza Bowers, Jr.: First, I want to thank you. Eda, and Dan, and everyone at the radio station KZYX and your listeners. This is such a great opportunity, because I recognize the fact that I don't exist in a vacuum, and at the same time, I understand that it is a tremendous responsibility because people listen to what people say sometimes and our voices have been silent for a long, long time. So this is a great opportunity and I really do appreciate this opportunity, and I'll try to let it flow.

Secondly, you might hear a lot of noise in the background. But it's not really noise It's other human beings, just like I'm situated, and they are 
getting ready to go and eat, and it might sound like feeding time at the Serengeti Plains.

Eda: I'm going to ask you to talk a bit about your personal backgroundwhere you grew up and went to school.

Veronza: I've given some thought about my childhood growing up. One thing about prison: it gives you an opportunity, if you take it, an opportunity to do a lot of reflecting upon your past.

I grew up in a little town in Oklahoma named McAlester-that's where they have a big penitentiary - I grew up in a very, very small tight-knit community, at a time when things were a lot different. And reflecting on that, I grew up primarily with the influence of women, because my father was away in the army. My father, Veronza, he did twenty-five years in the U.S. Army. So my mother, Dorothy ...

I'm glad you asked that question because in order to understand anything, you have to look at it in its totality, its connections - its historical connections, if you will. And growing up in this little town, surrounded by women as I was - because my grandmother had six children, five of them were women! and one son (we called him "Uncle Sonny")—-the little neighborhood that I grew up in, an all black neighborhood, we didn't have any experience with racism directly. Or all the conflicts that result from that.

Looking back on it, you think about poverty and being poor and all of those things, but back then, it was just always a very, very good feeling. My great grandmother, Granny, was my first real teacher of our story (it's called "history"). She was seven years old when slavery was abolished. She taught me a lot of things about that past. So my youth was very rich in tradition and stories. And I remember my grandmother (everybody called her "Bucker" but I called her "Grandma"), she was like the backbone of the Johnson/Larkins clan, and her word was law.

Growing up as a little boy like that, I learned [sic] to really listen to and appreciate the old people and what they had to say. Because they always were talking about "Life"- you know. That was a great joy for me to be able to sit around and listen to all those kinds of things.

And Mama was always "Mama". With my father being away all the time, she gave so much strength and understanding of the world around me. 
So, growing up in McAlester, Oklahoma-I was born in 1946 [the sound of many men in the background grows louder ... Eda, listen to this: you hear them call chow? It will get quiet in a minute so I won't have to speak so loud and so fast, maybe .... I've really come to the realization that when you start talking about the past, there's so much that happened, so many memorable experiences that you could wander on and on and on.

Eda: Would you talk a little bit about what it was like to be segregated and discriminated against.

Veronza: Eda, I never understood what segregation meant and what racism meant, and I never heard the word "nigger" because, as I say, I grew up in a black community where there was a lot of love and concern about each other.

I went to a little school, named L'Ouverture High — but it was from the first to the twelfth grade. We had to catch a bus and cross a little canal to hop on the bus to go way, way across town. And there was a little school right up the street about two and a half blocks on a dirt road. It was a very nice red brick school. I came to find out later, it was a grade school to junior high. That's where white people went to school. And I used to walk past it sometimes and look at it and wonder - what kind of teaching goes on in there that's so much different?

Later on in life I found out L'Ouverture High was named after Toussaint L'Ouverture, the great liberator down there in Haiti. They'd never taught us anything about that.

But that little town, as small as it was, thought it was normal.

Like when we wanted to go to the movie theater. Back then you paid five or ten cents to go to the theater. They had three movie theaters in the whole town - the News, the Chief, and the Okla. The News was the one where we could go to. I always wondered why we couldn't go to the other ones, but I didn't ever question that. And when we did go, we had to sit up in the balcony, and it was only on Saturday or Sunday that we could go.

One time they had this movie called "The Ten Commandments"-I remember just like I'm looking at it. They closed the theater and let all the black communities in. Third ward, Fourth ward and Fifth ward (our communities were called "wards"). That was for two weeks. And once that was over and they figured everybody had seen "The Ten Commandments" 
that were going to see it, they closed the movie theater down for another two weeks and fumigated the place, because we had been there.

Those experiences as a little boy-I would look at them then and wondering what all this was about. They still had the water fountains with signs: one water fountain said "Colored" and the other water fountain said "White". I remember on a sunny day, my father picked me up (because I'm too small to step on the water pedal and drink at the same time) so he picked me up and the water is coming up, and I look over at the other water fountain - I could read too, by then - and at the other water fountain a little white boy's father had him picked up. I'm looking at this water, and the water is sparkling because the sun is shining through the window, and when my father set me down I said, "Daddy, how come my water says 'Colored' and the other water says 'White' and they look both the same?" And I remember my father lifting me and he said "Boy, you'll understand those things later on in life". Those are the kind of little experiences, the accumulation of which, along with the lessons of my grandmother, that lead a little young mind like I had into questioning a lot of things that you see around you.

Eda: At what point did you became aware that because you were black you were being treated differently, and when did you realize you wanted to make a difference, and you wanted that to stop?

Veronza: You know, Eda, I don't think it was a particular point. It was just an accumulation of my experiences growing up, particularly in McAlester, Oklahoma, and then later on in Omaha, Nebraska. I think it was just the accumulation, starting back from my real education by my great grandmother, and then watching the women with the welfare and all of that kind of stuff going on in the neighborhood.

Then one day they came up with the desegregation of schools (I think that was 1954, with the "Brown vs Board of Education" decision by the Supreme Court) and I starting gong to that little school two and a half blocks up the way, and that's when I was called (to my knowledge) "nigger" for the first time.

Those kinds of things growing up. Becoming part of a wrestling team and going away to college. Being in the military, the US Navy for a short stint and going overseas in the Mediterranean. And along about that time 
(by then I guess I'm about twenty years old or so), Brother Malcolm X came on the scene with the Nation of Islam and that whole movement towards recognizing what they called "Negroes" at that time, as black people, people of African descent - that we were actually somebody, that we were human beings and not just the doormat of the world

And just listening - because I've always been a listener. I was raised that way - to listen to the old people, to listen to adults when they talk. And I took that listening and listened to a lot of things. And not just listened with my ears, but with my heart and feeling. And as I grew up and started looking around me, and I see what is considered poverty everywhere and that it is such a pervasive thing. Then going overseas and seeing how people live differently; coming back and seeing how we still are at the bottom of the pecking order, so to speak - the doormat of the world - and then hearing people like Malcolm (and even the Honorable Elijah Mohammed) talk about "do for self and pride in your own self". And then the pride I was given by my grandmother, Bucker. You know Eda, if I could, I would like to just give you a little idea through a poem that I wrote to my grandmother. She died in 1983. I used to write a lot of poetry and I wasn't allowed to go to the funeral. So I wrote this poem and sent it to my sister and asked her to read the poem - "To Grandma," that's the name of it-and place it on her chest, place it over her heart. I haven't written any poetry since. The poem goes like this:

Grandma, the silence of your heart brings pain to all who love you

Could I say goodbye to you in tears, I would

But somehow I know you would only smile and say

"Boy, Wipe your eyes. I'm free at last. I'm free at last.

Thank God, Almighty, I'm free at last."

So, Grandma, I'll remember you in your strength

You taught me to stand tall with pride and dignity

Although I live in shadow

At this moment in time

Grant me but the memory of you

Your face, your smile

In darkness then I live without fear

Lost though I may be for awhile

Wonderful memories of you sustain me 
And I know the meaning of hope

Reflections of you spring from my heart

To liberate me from the chains of men

Grandma, could I say goodbye to you in tears I would

But never can I say goodbye to all that you were

To all that you gave me

Grandma. may you rest in peace

And you know. I wrote that not just for Grandma, but the people of the community. You've got to have a real appreciation for the strength of a people who were able to withstand the discrimination, the exploitation, the oppression - that life - and still be able to love each other and hope for a better day.

I learned listening to people like Malcolm, and to my own heart, that not only should you hope for a better day, but you also have to struggle for it. So at one point in my life when I heard about the Black Panther Party being formed out in Oakland, California, and I read their platform and program, I said to myself "Man, maybe here we can do something to better the condition of our people." And then "Our People" expanded to be people who were [This call is from a federal prison.] living in a bad way.

And so I joined the Black Panther Party.

Eda: What did the Black Panther Party offer you? And what did you want to accomplish by getting involved?

Veronza: The Black Panther Party became a nation-wide organization and we established chapters for the state and branches in the cities all across the country where there were major (what people called) "ghettoes". We began to address some of the issues of our communities - the same ones that I'd seen growing up as a little boy.

Hunger. We established programs like free breakfast for school children - programs for any child that wanted to eat a healthy meal before they went to school. They could stop by at any of the places where we had that established, and have a good, healthy and wholesome breakfast because it's a hard thing to sit in school, trying to learn, and your stomach is growling, and you hear more of your stomach than you do the teacher. So, those kinds of issues. Or, like the old ladies would be going to the store and a youngster 
would come by and snatch her pocketbook. We addressed those kinds of issues. Even recruited some of those little youngsters to escort the ladies to the store and not be worried about being molested. Those types of positive programs in the community - doing for self-became like a vehicle. And I was just one of the many young men and women who were filled with a vision and a burning desire and a hope and a dream for a better future for our people. And so, we embarked upon that journey, not knowing where it would end. Or if it would end. But we knew we had to do something-not to mention the police brutality that was raging from coast to coast - and still is from coast to coast. We began to wrestle with a lot of those issues, and unfortunately (and history will bear it out) we were misaligned and attacked. And my incarceration is a direct result of that. Not because of something I have done, but because of my "political activity".

So that makes me one of the long-held political prisoners in this country. And I'm just one of many. And it is hard for me to just speak about myself. But because of the nature of this interview, I know that's necessary. But I can't be understood apart from a people and a movement. Because in reality, as a political prisoner-and that's known throughout the world - we were representatives of a people and we were accused of trying to overthrow the government and all kinds of foolishness. Because that was never the case. We were trying to make a better life for our own people. And for that - history will also absolve us on this - a war was declared against us, and many of us linger in prison now. For decades. I'm almost in my thirtieth year, and I'm still struggling.

Eda: Would you talk about what happened during your original case? What happened during that time and how old you were when you were convicted?

Veronza: I had never really been in trouble with the law, other than selling Black Panther newspapers and a lot of little miscellaneous charges they were using to try to disrupt the flow of activity. So, I was twenty-six when I got convicted of first degree murder of a National Parks Ranger. It was a very strange thing, because not ever having to have an experience with the law and justice and all that kind of stuff, sitting there in the courtroom, clearly things were running pretty ragged. Eda, I had some very good defense lawyers, and I could see they were doing their best, but I also could see that apparently the deck was stacked. 
I'm going to try to make it real brief and straight to the point. They had two main witnesses - one guy that I knew well (and I knew his brother even better) and another guy I had never met, although I knew his brother. The first guy, the main witness, testified that on the night of this killing that I was with him-which was a lie. And that I was the trigger man - which was a lie. And in exchange for his lie and his testimony (he had already been convicted of an unrelated bank robbery and had received twelve years), he wound up doing two years at some camp and received $\$ 10,000$ for his testimony.

The other witness - who I had never laid eyes on in my life - he had three cases pending in court for possession, sale and distribution of heroin. And in exchange for his testimony against me (he corroborated the main witness's testimony with another lie by saying that I came and told him everything that happened), the State's cases for possession and sale of heroin were dismissed and he received $\$ 10,000$. Plus, we had a 1973 Grand Prix that was taken, and it was awarded to him. He was rewarded with our own Grand Prix for his duplicity.

Those two testimonies, with no physical evidence, sealed my fate. And I've languished in prison ever since, unable to unravel that strange web that was weaved. Weaved at a time in history, Eda, when (as it is generally known, now) there was a program called COINTELPRO (Counter-Intelligence Program) that was designed to disrupt and neutralize the Black Liberation Movement, the Civil Rights Movement, the American Indian Movement. Many of us were victims of that program set up by J. Edgar Hoover and the FBI. And the web was spun so tight that we haven't been able to unravel it except in a couple of cases like Geronimo Pratt out in California. After 27 years, they finally proved it was a wrongful conviction and he was released and awarded something like four and a half million dollars. That does not amount to much for your life, and that is not a fair exchange.

And there was one other brother out of the Panther Party named Dhoruba Moore. After 19 years of wrongful conviction by the state of New York, he was awarded some million odd dollars. But that is in exchange for a life, and our lives are just as precious as anybody else's. We are political prisoners, and there are many others who are still lingering in prison in New York State and California and Maryland, and Mumia up there on Death Row in Pennsylvania. Leonard Peltier over there in Leavenworth. Eda, we just continue to try to do the best we can. To try to live and do the best we can. 
My case has so many clouds on it, and it's been through many procedures, but it can be summed up pretty quickly this way. I was arrested on state charges - a number of them and they were all dismissed, not only because of the search warrant (the Judge ruled the search warrant was illegal because there was no probable cause or anything). Back in those days there were a lot of fishing expeditions going on. And then, after the state charges were dismissed (each of them carried five-to-life in the State of California - three or four different charges), the "Feds" stepped in and charged me with the murder of this National Parks Ranger. And because there was no physical evidence linking me to the crime itself, the government chose to use two people who already had trouble with the law (one of them I thought was a friend of mine, and like I said, this other guy that I didn't know) and in exchange for their testimony and all the rewards that they got, the "Feds" secured a conviction.

I appealed all the way to the US Supreme Court, and of course, got no relief. And I haven't got any relief up until this day, including when I go to the Parole Commission. One of the things they require is that you show remorse for the crime that you committed, and from my first time going there in 1983 up until the present, I've always maintained my innocence. I explained to the Commissioners on more than one occasion that that places me in a dilemma, because it is one thing to have remorse and sorrow for something that you've done, but it's an impossibility to have remorse and sorrow for something that you haven't done. And I have made it very clear to them that I did feel sorrow during my trial when I heard the Ranger's wife testify about her husband-I could tell that she loved him. The taking of human life is something It shouldn't be taken lightly. But at the same time, I've expressed over and over again that my life, in essence, was taken without remorse for a crime I had nothing to do with.

So that's the thing I have had to deal with, coming into prison as a young man - by the time I got to Atlanta, I was just turning 27 and I've had all those birthdays in between. But basically, I became eligible for parole in 1983. I was sentenced to a life sentence, but in 1983 I became eligible for the first time for parole, and at that parole hearing they told me to continue to a full consideration hearing, which meant 1993. I took my court appeal all the way to the 11th Circuit and actually won the Appeal in the 9th Circuit, and that took ten years and the court ordered the Parole Commission to recompute my parole release date, give me an immediate new hearing, 
absent any erroneous and false information about an alleged assault that never took place - it took place, but I wasn't involved in it.

And the Commission went through the motion of giving me a new hearing, and then said "Continued until two-thirds expiration," which is 2004. Since 1983, I've gone to the Parole Board in '91, again in '93, '95, '98, 2000 (I haven't gone in 2002 yet.). And in 1993, for the first time, the Parole Board examiners recognized that something was wrong, and they attempted to give me a Parole Release date. They recommended I be released on December 7, 1998 and they awarded me 57 months for superior program achievement because there have been a lot of things I've done positive since I've been locked up. And it went to Washington and they took that back. And again in 1995, the Commissioners attempted to give me a 1998 release date, and again, it was taken back in Washington.

I appealed that decision, and thanks to the effort and support from numerous friends, too many to mention, I was able to get some very good legal representation. And now, we have a case in court down in Florida and it's right up to the ending point, whereas if the judge rules in my favor, I will get immediate release. If they rule not in my favor, then no doubt I'll be released in 2004 - if life lasts and death passes.

But it's been an on-going struggle with the Parole Commission. And I have to mention this, Eda, it's not just me. Particularly those who are considered political prisoners, like Leonard Peltier and Mumia Abu-Jamal in state prison, and many up in the state of New York - all over the country, about 150 of us. That's the treatment that we received-we received long sentences; in many cases, wrongfully convicted.

And in spite of the fact that we have pretty much been what they call "model prisoners" because we are who we are, we do what we do-in spite of all of that, we keep getting denied parole over and over again. Like Leonard just got denied parole on July 9th, this year [2002]. And Mumia got his case overturned insofar as the death penalty phase, and they're trying to re-sentence him either to life imprisonment or the death sentence.

But thanks to the many people whose eyes are now being opened, we're getting a lot of support. Because in the old days there was very, very little support. We were pretty much going on our own. Thanks to the untiring efforts of many people, I was able to get some very good legal representation. But in spite of that legal representation, the Parole Board has dug its heels in and has refused to honor its own rules, regulations and guidelines, as well as the law of the land. And so we have a case in court that addresses all those 
issues and it will be decided in the not so distant future. Maybe within a month or two. Hopefully, less than that. Obviously, I'm eligible to go every two years. So, I'm waiting.

Because when I went in the year 2000, represented by my attorneys, the examiner told me he recommended I be released on Sept 12, 2001. And as witnessed by our interview right now, this is 2002 and it's September 11th, and I still haven't been released. It's a lot of things that don't meet the eye. But at any rate, we continue to struggle.

Eda: How do you maintain the positive spirit—and sanity—after being in prison so long?

Veronza: That's a question I'm often asked by a lot of the youngsters that are around today-when I look around prison today (because I was one of the younger guys in prison back in those days in maximum security penitentiaries). And so I meet $a$ lot of young guys - young, very, very young with more time sentence-wise than they have been on the earth. Like 22 or 23 years old with life sentences and 45 years, and they often ask me: "Man, how do you do all of that time?" That's the question. But when you say how? Obviously, you just continue breathing - you know what I mean. But it's also (in my particular case) because I've always recognized that myself, as an individual, I'm just a part, a small part, of the suffering of a people.

And so even though I've suffered the pain and despair of being separated from my loved ones - my mama, she's 86 years old now and in bad health, and my daughter, when I left her, she was five years old, now she's just had her 36th birthday and married with two children, my grandkids. So that pain at that type of separation-longing to be with your family - can never go away. It's the 24/7 type of pain.

But I also recognize, when I look back and look at the suffering that Granny and Grandma and all the other grannies and grandmas and mommas and daddies and children who have been living lives that could be so much better (you know) if things had changed to some degree or another, that that individual pain and suffering is long-standing; and so, my suffering becomes very little when you compare it, or make the connection between that type of suffering and the suffering that I endure as an individual.

And I'm surely not saying that because I understand a few things I didn't when I was a little boy, if that makes it any easier. And of course with friends 
(and I could just name a whole list of friends and supporters who've given me courage, who've given me hope-guys in prison too [This call is from federal prison.] but a lot of people whom I have been in contact with over the years who have given unconditional love and support and friendship.

And then when you look at the struggle of peoples throughout the world, you recognize that you have to live life somewhere. And I recognize that. That whether I am in prison or out in the so-called "Free World" that I have to live my life somewhere. And I've determined long ago that I want to live it the best I can, and as fully as I can wherever I am and wherever I find myself.

In those maximum security penitentiaries back in the old days, you used to do a lot of "hard time", they called it. It reminds me of a poem:

Without the cold and disillusion of winter, there can never be the warmth and splendor of spring.

Calamity has hardened me and turned my mind into steel.

It's like the life of a willow tree: you learn to bend when you have to and weather the storm.

So people have told me: "Man, you seem to have found a way to maintain your sanity and dignity." And I remember reading in one of Nelson Mandela's books (you know, he did 27 years over there in South Africa, he and his comrades), he said one of the hardest things that they found doing that type of incarceration and misery, was how not to adjust. That you maintain your dignity and self-respect and honesty in dealing with people and you care for people.

I think I've done that because that's the way I was raised. And so when people look and say, "You're a strong man", it's not because I'm a strong man but because I was raised by strong women and a strong people. And I'm just blessed and thankful that some of those characteristics of those people I just mentioned found a way into my own heart. I just do the best I can, because I love people, and I love life, and I've been blessed and fortunate enough to have good people in my life.

Like a Master flute-maker I know named Monty, and an eloquent lady, Kayd, and your sister, Anna. Those in the Jericho Movement: Safiya and Paulette and Herman. My sisters Cynthia, Rhonda, Voni and Joi, Betty, 
Jean-Marie, Ovedia, Debbie, Debb. Mamma Mae, her beautiful daughter, Theriseta. My attorneys: Neoma Kenwood, who fought single-handedly for ten years, Curtis Crawford, Benjamin Malcolm (may they rest in peace), Edward Hammock and Donna Sullivan. John Neptune and the world of Shakuhachi. Maynard Garfield - the list goes on to where you just can't name all of the people who have influenced your life, and you accept that blessing as it comes.

One thing that I have to mention is that I had tried to escape from Lompoc in 1979, and I was shot and apprehended, as was my comrade. Archie Fire Lame Deer sent a couple of warriors over and invited us into a sweat lodge ceremony of Native Americans, and from that ceremony that day-it was a healing ceremony-I've adopted those ways and I walk that path of what is called the "Red Road". And that sweat lodge, the ceremonies - the discipline it takes and the connection with all living things - has made a significant change in my life.

Including Shakuhachi: the blowing, the using of the breath, connecting with your inner self in meditation. Those kind of things, and healthy exercise and trying to eat the best you can, you can still smile in spite of the harshness of the environment. Environments do make a difference, but I don't think they are the determining factor in how you view the world and how you respond to that world.

Because today is a lot different than it was in the old days. And particularly, Eda, this institution where I am-Coleman, Florida. It's the first time (after 26 years) that I came to a lower-level security-type institution. It's unlike any other place I've been. I've never experienced an administration like this one. Here, because of the broad vision of the warden and his administration, we're allowed to have quite a few programs that are meaningful. Programs in the sense that the guys can contribute something back to society. We have a little program we call YES-Youth Encouraging Support-wherein we are able to make contact through our program with young kids who they call "trouble kids", but they really are kids in trouble, kids from the ages eight, nine, ten, eleven, twelve, thirteen, fourteen who have been in trouble with the law. We're able to sit with them in the visiting room and interact and exchange a lot of ideals and feelings and thoughts - to try to make a difference.

We have a program called "Non-Violence Training Outreach", an outreach program teaching guys self-respect and character building. We have 
a Fine Arts Department where we put on plays that are slices of life. These types of programs, because of the way things are going today, have not been allowed in many, many places. So I think we're like pioneering and laying the groundwork for the future. Because today, there are so many young guys coming into prison, many of them without a GED or communication skills. And we're able to make a difference. And that is very meaningful to me as an individual. So even though prison is a place where no one wants to be, because we are here, some will make a positive use of their years of confinement — and some don't. And it's real painful and terrible to see those that don't, who often times, through no fault of their own.

At any rate, all the little things combine together to either make you into a better human being or break you and make you unrecognizable as a member of the human family when you are released.

Eda: Today marks the anniversary of the attacks on the Twin Towers and the Pentagon which resulted in the deaths of thousands of Americans and undocumented workers. Could you describe what happened inside the prison that day, and how it has changed since September 11 $1^{\text {th }}$ ?

Veronza: On that particular day, it was probably like everywhere else. What happened was something that we couldn't have even believed to be possible - the loss of that many lives all at once. And not just the lives that were lost immediately, but the families, the things and everyone that was affected by it.

There is one guy here, Siokatarne Hafoka from the island of Tongathat's way in the middle of the Pacific - he's a member of our Sweat Lodge ceremony. He's a big gentle giant - I mean a huge guy - and he's a gentleman and has a heart as big as he is. Big. And this guy (there are about 1,700 people here in this institution) was so affected (as many people were), he fasted every single Tuesday until today - until yesterday - which made it a whole year of fasting - without food or water. Just to remember that day and remember the spirit of what had happened.

I know that in other institutions, there was lockdown, meaning everybody was locked into their cells. But this place is a lot different than a lot of other places and we didn't directly experience that, although a few guys got locked up because of their religious affiliations with Islam.

And you hear a diversity of attitudes. But I myself recognize that not only 
were a lot of innocent lives lost here, but that there have been repercussions on the people of Afghanistan and that people throughout the world have been affected by what happened that day. I think it was something like 2,824 people have been identified through body parts that have been found. In my own mind and heart that was a great tragedy. And like in all wars of all times, war is a mutual slaughter of men and women, and those kinds of things, they can only sadden the heart.

Eda: If there was one thing that you could change in this world, what would it be?

Veronza: I would love to be able to change the relations among men-when I say "men" I'm also including women. Humankind.

Because we talk about war, poverty, hunger and misery on the one hand, but its opposite always exists. But it evolves down to the relationships. Relationships to me are very, very important, and if there is to be a world free of sexism and fascism and ageism and all those other "isms" and schisms that divide humankind - not to mention racism, which is an artificial division of human beings based upon skin color, or positions and stations of life...

If we could go back in time to that time called "primitive communal society", but really was a society when there was a lot of collective and mutual co-operation in order to survive against the beasts of prey and the forces of nature that man didn't understand; if things could be ordered in such a way (not ordered in a sense of a dictatorial thing) but ordered by mutual respect.... Like the way I grew up in a community. The elders had respect, not because they had authority imposed upon those who gave the respect, but because that respect was well-earned and understood. And that's the type of respect that even great presidents and generals and foreign ministers don't have, [This call is from a federal prison] because those things are not something that can be forced upon a people.

So if those relations change-relations to the point of production - then we could have a much better world where a woman would never know what it is to have to give up her body in prostitution, or people would never know what it was like to grow up in slavery, a beast of burden. That's what I would hope for my children and grandchildren and the children after them, and yours, and those yet to be born. And it could be so. But that requires 
a lot of struggle and a lot of sacrifice and a lot of willingness of people to understand that unless we co-operate as a human species, then we are going to perish.

Eda: Is there some advice you would like to tell youth in America today?

Veronza: Yeah. It's been said (and it's not rhetorical) that the youth are like the sunshine at eight or nine o'clock in the morning - bright, full of beauty and vigor. And they will visit places where those of my generation and other generations can't even dream of, yourself included. You have places to go that can only be dreamed of. So, the youth have a great responsibility, like all generations that come after the generation that's currently trying to make a better world. The youth have to take a sober look at that. Not in the sense of foregoing all the joys of life that come with youth, but recognizing that youth, just like old age, is a passing thing, and it's here now and it will be gone.

So we listen to our past, reflect on our past, and plan for the future and live in the moment. Often we see that youth have been criminalized as a generation. They still are our hope, because they are going to be the future leaders of tomorrow. And so, that responsibility that they have, that has been squarely laid on their shoulders, it will be a heavy burden. But I have full confidence in our youth - the hip-hop generation.

Every generation has its ways. The youth of today are very much in tune with life and the world around them. You hear it in the music, you hear it in the rap music; you see it in their dance, the way they walk and talk. It's just a matter of being willing to listen, as we all have problems listening when we are young. I pin my hopes upon the youth.

And when I see these youngsters come into the programs I was telling you about - we'll be out in the visiting room talking and you look in their eyes and sometimes you see despair, and sometimes a few sparks flare up, and your heart hurts inside because, without some changes, you know a lot of people will live half-butchered lives, who could otherwise live meaningful lives - not just in the sense of being professional people like doctors and lawyers, but just contributing positive things to their own communities, and to their own families. That's where it starts, with the family. And it goes out from there to the community and to the city and the state and the nation. And the world.! 
Eda: What are your own future plans when you finally get out in the year 2004 ?

Veronza: If that happens,and like my mama always says, "If life lasts and death passes". In other words, if I keep breathing and I am fortunate enough to be released in 2004 (or if I win my case down here in the court that I have going now and am released immediately), I have a lot of plans.

One is to try to keep breathing, living. And I would really like to be able to open up a Meditation Healing Clinic. Over the years I've studied and learned and practiced acupressure and hands-on-healing and pseudo-therapy, and a variety of healing aids including blowing shakuhachi as a means of selfmeditation healing, and have gained some insights and rewards doing all of that stuff to relieve pain. Pain is a thing people don't have to necessarily live with, or "learn to live with" as the medical profession often says. But pain can be relieved with the touch of a finger or the sound of a note or the sound of a voice or a birdsong. I would like to try my best to open up a clinic of that nature and train some youngsters in that art of caring, and try to make a little difference in some lives, and take it from there. [Loud commotion sounds like: Closed, closed, prepare for ...] That's a big announcement.

Anyway, I really have to say that I'm very happy that my mother, who is 86 years old, and my daughter Veronica, even though they suffered so much pain in my absence, that they've understood that I had to follow my dream for a better world for us all. [This call is from a federal prison.] Because at one time, I don't think they understood. But they do now. And those kinds of things help one situated like myself to continue. Those are the kinds of things that mean so much. And I want to thank you, and I want to thank Dan, and I want to thank all of the people at KZYX and all of you listeners who put up with all of my ramblings. Obviously, I definitely want to thank all of the people who have believed in me and have supported me. And I can only hope that they will continue, and that somehow in the future, that my own life, what I have left of it, will be used in a way that is befitting that type of unconditional love and support.

[This call is from a federal prison. This is a prepaid call. This call is from ... Veronza.]

Eda: This concludes my interview with Veronza Bowers, Jr., a former Black Panther who's been incarcerated for 32 years and claims his innocence. 
He was speaking from the federal penitentiary in Coleman, Florida on September 11, 2002. If you would like more information about Veronza, or an up-date on his current case, please log on to www.geocities.com/ veronzab. To contact me, e-mailme at eda@pacific.net.

This has been a special edition of YouthSpeaksOut produced by Dan Roberts and Eda Levenson. YouthSpeaksOut has its own website at www. youthspeaksout.net. There you can find more information about the project, get addresses for contacting us and listen to many hours of previous programs in streaming audio. We really encourage our listeners to give us feedback on our shows. You can do this through e-mail at the website, or by writing us at:

YouthSpeaksOut

P.O. Box 1

Philo CA

95465

YouthSpeaksOut is broadcast live on the last Sunday of the month at $6 \mathrm{pm}$. Produced by Dan Roberts \& Eda Levenson

Broadcast on KZYX/Z, Philo CA 12/29/02

Text (C) Dan Roberts 2002

Note:

After being held in continuous custody and denied parole for over 30 years, Veronz Bowers reached his mandatory release date on April $7^{\text {th }}$, 2004. He was one of the longest held political prisoners in the US and had a record of over 20 years of exemplary conduct. An entourage of family and friends arranged a celebration of Veronza's release and to be at the prison gates to greet him on that day. Inside the prison, friends came together to wish him well. Veronza gave away all of his possessions to the men whom he was leaving behind.

On April $6^{\text {th }}$, he was advised that he would not be released, on the orders of the National Parole Commission. 